\title{
The impact of scrubber discharge on the water quality in estuaries and ports
}

\author{
Johannes Teuchies $^{1 *}$ (D), Tom J. S. Cox ${ }^{2,3}$, Katrien Van Itterbeeck ${ }^{4}$, Filip J. R. Meysman ${ }^{2,5}$ and Ronny Blust ${ }^{1}$
}

\begin{abstract}
Background: The International Maritime Organization (IMO) has set limits on sulphur content in fuels for marine transport. However, vessels continue to use these residual high-sulphur fuels in combination with exhaust gas cleaning systems (EGCS or scrubbers). Next to high sulphur, combustion of these fuels also results in higher emissions of contaminants including metals and PAHs. In scrubbers, exhaust gases are sprayed with water in order to remove SOx, resulting in acidic washwater with elevated contaminant concentrations discharged in the aquatic ecosystem. The number of vessels with scrubbers is increasing rapidly, but knowledge on washwater quality and impact are limited.

Results: The scrubber washwater is found to be acidic with elevated concentrations of, e.g. zinc, vanadium, copper, nickel, phenanthrene, naphthalene, fluorene and fluoranthene. Model calculations on the effects of scrubber discharge under scenario HIGH (20\% of vessels, 90 th percentile concentrations) on the water quality in harbour docks showed a decrease in pH of 0.015 units and an increase in surface water concentrations for e.g. naphthalene (189\% increase) and vanadium (46\% increase).

Conclusions: The IMO established sulphur regulations to mitigate the impact of high sulphur emissions of the maritime sector. However, the use of open-loop scrubbers as an abatement technology will not reduce their contribution to ocean acidification. In addition, different types of scrubbers discharge washwater that is acutely toxic for aquatic organisms. However, washwater is diluted and the compounds for which a large increase in surface water concentrations was calculated in the Antwerp (Belgium) harbour docks (naphthalene $>$ phenanthrene $>$ fluorene $>$ acenaphthene > vanadium) were not the compounds that already exceed their respective Water Quality Standards (WQS). Nevertheless, the WQS of several 'priority hazardous substances' (Water Framework Directive) are already exceeded in the docks and the Scheldt estuary. Since these hazardous substances are also identified in the washwater, scrubber washwater discharge should be discouraged in coastal waters and estuaries with large ecological value.
\end{abstract}

Keywords: Marine traffic, Pollution, EGCS, SECAs, Water quality, Acidification

\section{Background}

International shipping has a significant effect on air quality, with a contribution to global emissions of more than $20 \%$ for nitrogen oxides $\left(\mathrm{NO}_{\mathrm{x}}\right)$, around $10 \%$ for sulphur oxides $\left(\mathrm{SO}_{\mathrm{x}}\right)$ and almost $8 \%$ for particulate matter (PM) $[1,2]$. This has a number of environmental consequences [3], such as ocean acidification [4] and disturbance of

\footnotetext{
*Correspondence: johannes.teuchies@uantwerpen.be

${ }_{1}^{1}$ Department of Biology, Systemic Physiological and Ecotoxicological Research, University of Antwerp, Groenenborgerlaan 171, 2020 Antwerp, Belgium

Full list of author information is available at the end of the article
}

climate regulation [5], and also impacts human health in coastal regions through deteriorated air quality $[6$, 7]. To mitigate these effects, the International Maritime Organization (IMO) has included annex VI (Prevention of Air Pollution) to the International Convention for the Prevention of Pollution from Ships (MARPOL). This has resulted in a global cap on sulphur in fuel oil of $3.5 \%$ (mass percentage) from 2012 and a maximum sulphur content of $0.1 \%$ in dedicated $\mathrm{SO}_{\mathrm{x}}$ Emission Control Areas (SECA's) from 2015 onwards [8]. A new stringent global limit on fuel sulphur content of $0.5 \%$ came into force on January 2020.
SpringerOpen

(c) The Author(s) 2020. This article is licensed under a Creative Commons Attribution 4.0 International License, which permits use, sharing, adaptation, distribution and reproduction in any medium or format, as long as you give appropriate credit to the original author(s) and the source, provide a link to the Creative Commons licence, and indicate if changes were made. The images or other third party material in this article are included in the article's Creative Commons licence, unless indicated otherwise in a credit line to the material. If material is not included in the article's Creative Commons licence and your intended use is not permitted by statutory regulation or exceeds the permitted use, you will need to obtain permission directly from the copyright holder. To view a copy of this licence, visit http://creativeco mmons.org/licenses/by/4.0/. 
To comply, ships can use compliant low sulphur fuel oil or alternative fuels which are low in sulphur, such as liquefied natural gas (LNG) or methanol. The IMO sulphur limits only apply to atmospheric emissions. Consequently, it is allowed to continue to use high-sulphur fuels in combination with an exhaust gas cleaning system (EGCS or scrubber). In scrubbers, the exhaust gases of vessels are sprayed with liquid in order to remove the $\mathrm{SO}_{\mathrm{x}}$ before it will be emitted to the air. Scrubbers are capable of removing up to $95 \%$ of the $\mathrm{SO}_{\mathrm{x}}$ in the exhaust gases and meet the IMO sulphur exhaust limits [9]. Most scrubbers installed on vessels are wet scrubbers and use 'open loop' or 'closed loop' systems. Open-loop systems, also referred to as seawater scrubbing technology, dominate the market. In these systems, the exhaust gases are sprayed with seawater at a high flow rate, and the $\mathrm{SO}_{\mathrm{x}}$ in the exhaust gas is trapped and converted to sulphurous acid $\left(\mathrm{SO}_{3}{ }^{2-}\right)$ and sulphuric acid $\left(\mathrm{SO}_{4}{ }^{2-}\right)$. The washwater generated in the scrubber is discharged in the surrounding surface water at a typical flow rate of $200-500 \mathrm{~L} \mathrm{~s}^{-1}$ for a vessel operating at $15 \mathrm{MW}$. Alternatively, closedloop systems use freshwater as the scrubbing medium, which is pre-treated with sodium hydroxide $(\mathrm{NaOH})$. This washwater recirculates in the scrubbing system. The scrubbing capacity is maintained by dosing extra $\mathrm{NaOH}$ and periodically discharging smaller volumes of washwater, typically $0.5-3 \mathrm{~L} \mathrm{~s}^{-1}$ on average for a vessel operating at $15 \mathrm{MW}$. Also 'hybrid systems' exist, whereby vessels can shift the scrubber operation between open- or closed-loop mode.

Given the fairly recent changes in the IMO sulphur regulations, the amount of vessels equipped with scrubbers is still limited, but changing rapidly. According to Clarksons World Fleet Register, consulted in November 2019, nearly 3000 scrubbers have already been installed, which corresponds to $3 \%$ of the total number of vessels and $16 \%$ of the gross tonnage. This implies that mainly large vessels invest in a scrubber. Additionally, $15 \%$ in numbers or $35 \%$ in gross tonnage of all vessels ordered at this moment (November 2019) will have a scrubber installed. From an economical perspective, scrubbers are an attractive option, particularly for larger vessels $[10,11]$. In order to comply, the choice between using the more expensive low-sulphur fuels or the installation of a scrubber depends largely on the price difference between both, low-sulphur fuels and common heavy fuels [12]. Depending on the conditions, the scrubber installation costs are found to be recouped within the span of $1-2$ years [13, 14]. The number of scrubbers is predicted to continue to increase after the implementation of the more restrictive global sulphur cap in 2020.

The use of scrubbers results in a shift of the environmental impact of sulphur from emissions to the atmosphere towards a direct discharge into aquatic systems. Further, the high-sulphur fuels used by vessels with scrubbers are generally heavy fuel oils (HFO), which are residual fuels incurred during the distillation of crude oil. Together with high sulphur emissions, these fuels are known to result in higher emissions of other hazardous species including metals and polycyclic aromatic hydrocarbons (PAHs) compared to low-sulphur distillates such as marine gas oil (MGO). These contaminants originate from higher concentrations of, e.g. metals and PAHs in the fuel and larger emissions during combustion of this residual fuel [15]. Several studies report that scrubbers reduce the atmospheric emissions of $\mathrm{SO}_{\mathrm{x}}$ or $\mathrm{PM}$ to a level that is comparable to emissions when operating on MGO [16-20]. However, PM emissions and removal by scrubbers depend on many factors and lower removal efficiencies from scrubbers resulting in higher emissions of particles including black carbon and PAHs compared to vessels operating on MGO have been reported [21, 22]. In addition, scrubbers are an end-of-pipe solution and a substantial part of the emitted compounds will be trapped in the scrubber washwater and discharged in the surrounding surface water with potential consequences for aquatic ecosystems [18, 23-26]. Existing studies are limited, mainly focus on open marine systems and conclude that the overall impact of scrubber use on $\mathrm{pH}$ changes and contaminant concentrations is expected to be small under most conditions [24, 27-29]. Yet, the long-term accumulation of contaminants caused by scrubber discharge can be of concern in smaller water bodies where ships are numerous, such as estuaries or harbours [30, 31].

Data on washwater contaminant concentration are scarce, often proprietary and rarely published. In present study, an extensive dataset on washwater contaminant concentrations and acidity is compiled, based on own measurements and unpublished and published datasets. This data allowed us to calculate the impact of scrubber use on water quality for two scenarios (10\% and $20 \%$ scrubber use) for the Antwerp harbour docks and the Scheldt estuary. While the IMO regulatory framework primarily focuses on atmospheric emissions, also the discharge of washwater is regulated to a certain extent. Washwater discharge guidelines are set for $\mathrm{pH}$ (min. of 6.5, measured at $4 \mathrm{~m}$ from the overboard discharge point), for PAHs (max. $50 \mu \mathrm{g} \mathrm{L}^{-1} \mathrm{PAH}$ Phe equivalent at a flow rate of $45 \mathrm{~m}^{3} \mathrm{MWh}^{-1}$ ) and turbidity (max. 25 NTU (nephelometric turbidity units) above the inlet water turbidity) (IMO, Resolution MEPC.184(59) and MEPC.259(68)). No criteria for metals are included. However, in current Belgian legislation the discharge of contaminated water from ships into their surrounding surface water is only accepted in several exceptional 
cases (e.g. wastewater from kitchens) [32]. Consequently, the use of open-loop scrubbers or closed-loop scrubbers with bleed-off discharge is not allowed in Belgian inland waters. To comply, vessels need to operate on compliant low-sulphur fuel or use scrubbers in closed-loop mode with the boundary condition that no washwater is discharged (zero discharge mode). While there is no current impact of scrubbers on Belgian water bodies, it is important to get insight into possible consequences for European ports, rivers, estuaries and coastal regions in order to streamline legislation. Ahead of the implementation of the SECA's, shipowners have already criticised the uncertainty and the inconsistency between the Member States on the use of scrubbers in order to comply with the requirements of the Sulphur Directive. In an open letter, the European Community Shipowners' Association (ECSA) urges that establishing legal certainty about proper compliance and enforcement together with a fair level playing field between shipping operators and between transport modes are a must [33].

The objective of present study is to identify contaminant concentrations in scrubbers washwater and get insight into effects of scrubber discharge on the water quality, with emphasis on harbour docks, rivers and estuaries.

\section{Methods}

\section{Sampling}

Washwater samples were collected from two separate marine vessels operating a scrubber. The first vessel was equipped with a hybrid scrubber and was sampled in Belgium on two occasions in October 2014: when at berth in the port of Antwerp, operating in closed loop mode and when sailing on the Scheldt estuary in open loop mode. The second vessel had an open-loop scrubber and was sampled twice in October 2015: when sailing at the North Sea and when manoeuvring in the port of Antwerp. Discharge and sampling of washwater in these Belgian waters was permitted by the Flemish Environmental Agency for present research. Detailed information on scrubber type, fuel and operating conditions can be found in the datasheet (Additional file 1: Table S1). Samples were taken from a tap close to the scrubber outlet. Right after sampling the temperature $\left({ }^{\circ} \mathrm{C}\right)$ and $\mathrm{pH}$ were measured with a temperature- $\mathrm{pH}$ electrode connected to a portable multi-meter (HQ30D, Hach, US). Water samples were collected in 1-L glass bottles for PAH analysis and in 0.25-L high-density polyethylene (HDPE) bottles for metal analysis. All samples were stored cool during transport. Metal analyses were performed after acid digestion with $\mathrm{HCl}$ and $\mathrm{HNO}_{3}$ by inductively coupled plasma optical emission spectrometry (ICP-OES) following standard method ISO 11885.
Measured metals are arsenic (As), cadmium (Cd), chromium $(\mathrm{Cr})$, copper $(\mathrm{Cu})$, mercury $(\mathrm{Hg})$, lead $(\mathrm{Pb})$, nickel $(\mathrm{Ni})$, zinc $(\mathrm{Zn})$ and vanadium $(\mathrm{V})$. PAHs were determined by gas chromatography/mass spectrometry (GC/MS) following standard method EPA 8270 D. Measured PAHs are acenaphthene (Ace), acenaphthylene (Acy), anthracene (Ant), benzo(a)anthracene $(B(a) A)$, benzo(a)pyrene $(\mathrm{B}(\mathrm{a}) \mathrm{P})$, benzo(b)fluoranthene $(\mathrm{B}(\mathrm{b}) \mathrm{F})$, benzo(g,h,i)perylene $(\mathrm{B}(\mathrm{ghi}) \mathrm{P})$, benzo $(\mathrm{k})$ fluoranthene $(\mathrm{B}(\mathrm{k}) \mathrm{F})$, chrysene $(\mathrm{Chr})$, dibenzo(a,h)anthracene $(\mathrm{D}(\mathrm{ah}) \mathrm{A})$, fluoranthene (Fluoran), fluorene (Flu), indeno(1,2,3c-d)pyrene $(\mathrm{I}(123 \mathrm{~cd}) \mathrm{P}$, naphthalene (Naph), phenanthrene (Phe) and pyrene (Pyr). These results were combined with additional datasets on $\mathrm{pH}$, metal and $\mathrm{PAH}$ concentrations: (1) unpublished datasets from the same shipping companies as sampled in the present study; (2) dataset resulting from sampling campaigns organised by the exhaust gas cleaning system association (EGCSA) and the association representing port waste reception facility providers (EUROSHORE) [34] and (3) from literature [24, 26-28, 35]. Results are combined in a database (Additional file 1: Table S1). Parameters with many values below limit of quantification (BLOQ) were excluded from further analysis (Additional file 2: Figures S1, S2, Table S2).

\section{Scenarios and model calculation}

To calculate the impact of discharged washwater on the water quality, two scenarios were defined. Scenario LOW assumed that $10 \%$ of the total ship emissions were treated by scrubbers and vessels discharged at average washwater concentrations. Scenario HIGH assumed a $20 \%$ treatment by scrubbers and discharge at 90th percentile of washwater concentrations (Table 1 for scenario HIGH, Additional file 2: Table S3 for scenario LOW). Both scenarios were calculated for closed-loop mode and openloop mode separately. From January till November 2019 about 350 unique vessels equipped with a scrubber visited the port of Antwerp, with a total of approximately 1250 calls (information Antwerp Port Authority and Clarksons World Fleet Register). This corresponds to $8.7 \%$ of the total number of vessels and $9.5 \%$ of the total number of calls. Scrubber types of vessels in the Antwerp port are evenly distributed between open loop and hybrid scrubbers. It is difficult to estimate the future use of scrubbers. Since the installation of a scrubber is economically profitable under most scenarios [11], a further increase can be expected. However, the fuel marked is changing rapidly and low-sulphur heavy fuels which are cheaper than distillates are becoming available and might influence scrubber interest [1]. The calculated scenarios included all fuel used by the vessels, from main and auxiliary engines. For manoeuvring and berthing in harbours, auxiliary engines are typically used. As these auxiliary 
Table 1 Summarising numbers on scrubber washwater concentrations, fluxes and impact on water quality for scenario HIGH (20\% scrubbers)

\begin{tabular}{|c|c|c|c|c|c|c|c|c|c|}
\hline & Units & Conc. docks (1) & WQS (2) & CLOSED loo & -scenario HIGH & & OPEN loop- & enario HIGH & \\
\hline & & & & $\begin{array}{l}\text { Discharge } \\
\text { conc. (90th } \\
\text { perc.) }\end{array}$ & $\begin{array}{l}\text { Flux kg year-1 } \\
(20 \% \\
\text { scrubbers) }\end{array}$ & $\begin{array}{l}\text { Conc. increase } \\
\text { docks }\end{array}$ & $\begin{array}{l}\text { Discharge } \\
\text { conc. (90th } \\
\text { perc.) }\end{array}$ & $\begin{array}{l}\text { Flux kg year-1 } \\
(20 \% \\
\text { scrubbers) }\end{array}$ & $\begin{array}{l}\text { Conc. } \\
\text { increase } \\
\text { docks }\end{array}$ \\
\hline $\mathrm{Cr}$ & $\mu g \mathrm{~L}^{-1}$ & 3.34 & 5 & 10,120 & 448 & 0.122 & 45.0 & 342 & 0.093 \\
\hline $\mathrm{Cu}$ & & 8.38 & 7 & 1780 & 78 & 0.021 & 130 & 998 & 0.273 \\
\hline $\mathrm{Ni}$ & & 5.86 & $4^{*}$ & 6060 & 268 & 0.073 & 127 & 994 & 0.272 \\
\hline $\mathrm{Zn}$ & & 32.9 & 20 & 1524 & 66 & 0.018 & 260 & 1863 & 0.509 \\
\hline V & & 3.94 & 4 & 25,000 & 1107 & 0.303 & 500 & 4069 & 1.112 \\
\hline Ace & $n g L^{-1}$ & 4.92 & 60 & 745 & $3.28 \mathrm{E}-02$ & $8.96 \mathrm{E}-03$ & 648 & 5.27 & 1.44 \\
\hline Acy & & 7.20 & 4000 & 185 & 7.87E-03 & $2.15 E-03$ & 536 & 4.34 & 1.19 \\
\hline Ant & & 2.67 & $100^{*}$ & 446 & 1.96E-02 & 5.37E-03 & 308 & 2.50 & 0.685 \\
\hline Fluoran & & 9.51 & $6.3^{*}$ & 661 & $2.88 \mathrm{E}-02$ & $7.89 E-03$ & 478 & 3.84 & 1.05 \\
\hline Flu & & 3.72 & 2000 & 2370 & $1.05 \mathrm{E}-01$ & $2.86 \mathrm{E}-02$ & 1200 & 9.81 & 2.68 \\
\hline Naph & & 8.24 & $2000^{*}$ & 6370 & $2.82 \mathrm{E}-01$ & $7.70 \mathrm{E}-02$ & 6960 & 57.0 & 15.6 \\
\hline Phe & & 7.95 & 100 & 6970 & $3.08 \mathrm{E}-01$ & $8.43 \mathrm{E}-02$ & 3700 & 30.3 & 8.28 \\
\hline Pyr & & 13.0 & 40 & 554 & $2.40 \mathrm{E}-02$ & $6.55 \mathrm{E}-03$ & 1220 & 9.90 & 2.71 \\
\hline Total PAH & & 58.1 & & 22,200 & $9.80 \mathrm{E}-01$ & $2.68 \mathrm{E}-01$ & 13,620 & 111 & 30.4 \\
\hline
\end{tabular}

(1) Average values for total concentrations in the harbour docks

(2) Water quality standards (WQS) from the EU WFD $\left(^{*}\right)$ or Flanders (dissolved concentrations for metals, total concentrations for PAHs)

engines are not always connected to the scrubber, the calculated changes in metal and PAH concentrations in the harbour docks surface water could be an overestimation.

The contaminant input $J_{\mathrm{c}}\left(\mathrm{kg}_{\mathrm{g}} \mathrm{year}^{-1}\right)$ to the water bodies (harbour docks and estuary) was calculated as:

$$
J_{\mathrm{c}}=Q_{\mathrm{w}} * P_{t} * F_{\mathrm{s}} *\left(C_{\mathrm{c}}-C_{\mathrm{d}}\right),
$$

with $Q_{\mathrm{w}}\left(\mathrm{L} \mathrm{MWh}^{-1}\right)$ the discharge of washwater (closed or open loop) per unit of generated power of the vessel, $P_{t}\left(\mathrm{GWh}_{\mathrm{year}}^{-1}\right)$ is the total power generated by all vessels in a certain water body (harbour docks or Scheldt estuary), $F_{\mathrm{s}}$ the share of total emissions treated by scrubbers ( 0.1 for scenario LOW or 0.2 for scenario HIGH), $C_{\mathrm{c}}\left(\mathrm{kg} \mathrm{L}^{-1}\right)$ is the concentration of the contaminant in the washwater and $C_{\mathrm{d}}$ is the concentration of the contaminant in the docks. The power $P_{t}$ generated by the vessels in the Scheldt estuary (182 GWh year $\left.{ }^{-1}\right)$ and Antwerp harbour docks (472 GWh year ${ }^{-1}$ ) is well constrained (data provided by the Antwerp port Authority). An average washwater discharge was calculated for open loop $\left(87 \pm 50 \mathrm{~m}^{3} \mathrm{MWh}^{-1}, N=44\right)$ and closed loop $\left(0.47 \mathrm{~m}^{3} \pm 0.25 \mathrm{~m}^{3} \mathrm{MWh}^{-1}, N=7\right)$, based on the available data (Additional file 1: Table S1). Note however that in very few cases vessels with closed loop systems will not discharge any washwater, as they retain the washwater on board and deliver it to port reception facilities on shore (personal communication shipping companies). The concentrations of metals and PAHs measured in the inlet water were not used for the calculation because values were often below limit of quantification (BLOQ). Additionally, concentrations of, e.g. zinc in inlet water samples were sometimes unrealistically high (Additional file 1: Table S1), which can be caused by sampling inlet water from a valve on board which could have resulted in elevated metal concentrations originating from the metal tubing of the scrubber system. Instead, available data on total metal and PAH concentrations in the harbour docks $\left(C_{\mathrm{d}}\right)$ were used and average values were subtracted from the outlet concentrations prior to the calculation of fluxes and changes in surface water concentrations (see Table 1 for concentrations). All outlet washwater concentrations reported as BLOQ were replaced by the respective $L O Q / 2$ and included in the calculations.

Changes in contaminant concentrations in the surface water resulting from the scrubber discharge are calculated as:

$$
\Delta C_{\mathrm{c}}=\frac{J_{\mathrm{c}}}{Q_{\mathrm{r}}},
$$

with $\Delta C_{\mathrm{c}}\left(\mu \mathrm{g} \mathrm{L} \mathrm{L}^{-1}\right)$ the mean concentration change in the receiving water body caused by scrubber discharge, $J_{\mathrm{c}}$ $\left(\mathrm{kg} \mathrm{year}^{-1}\right)$ the contaminant input from scrubbers calculated with Eq. 1 and $Q_{\mathrm{r}}\left(\mathrm{L}\right.$ year $\left.{ }^{-1}\right)$ is the water flowrate through the receiving water body. The mean flow rate of the Scheldt estuary was $100 \mathrm{~m}^{3} \mathrm{~s}^{-1}$, for the Antwerp harbour docks $Q_{\mathrm{r}}$ was the sum of the flow rate $\left(16 \mathrm{~m}^{3} \mathrm{~s}^{-1}\right)$ 
and the dispersive exchange $D$ through the locks $\left(100 \mathrm{~m}^{3} \mathrm{~s}^{-1}\right.$, see Additional file 2: Appendix for calculation). Calculation assumptions were that all discharged contaminants were evenly distributed in the water column and stayed in suspension, i.e. during their stay in the docks (average residence time $=19$ days) and in the estuary (average residence time $=2.5$ months). Calculated increase in concentrations were compared with surface water concentrations measured during regular water quality monitoring programmes from 2015 to 2016 in the receiving water body (data from the Flemish Environmental Agency and Antwerp Port Authority; in the docks $n=15$ (metals) and $n=15$ (PAHs), and in the Scheldt estuary $n=115$ (metals) and $n=20$ (PAHs).

For changes in TA, SumCO $\mathrm{O}_{2}$ and $\mathrm{H}_{2} \mathrm{SO}_{4}$ in the harbour docks a dynamic model was set up. In this model, the docks are considered well mixed. The water body is affected by influx of freshwater $\left(16 \mathrm{~m}^{3} \mathrm{~s}^{-1}\right.$, fixed water composition, data provided by the Antwerp port Authority), by exchange with the adjacent estuary over the locks (data provided by the Flemish Environmental Agency, fixed water composition of the estuary, dispersive flux proportional to concentration difference, fixed bulk dispersion coefficient of $100 \mathrm{~m}^{3} \mathrm{~s}^{-1}$, see Additional file 2: Appendix), by the scrubber efflux, and by gaseous exchange with the atmosphere. The $\mathrm{CO}_{2}$ (aq) in scrubber effluent was assumed to be in equilibrium with $\mathrm{CO}_{2}$ in flue gas and assumed to have a fixed partial pressure of $0.1 \mathrm{~atm}$ [36]. The carbonate balance in the scrubber effluent was computed at observed effluent water temperature $\left(T=25{ }^{\circ} \mathrm{C}\right)$. Scrubber flux of $\mathrm{H}_{2} \mathrm{SO}_{4}$ and TA were determined by assuming that all sulphur in the exhaust is captured by the washing process. Further, $20 \%$ of vessels equipped with an open loop scrubber, $2.1 \%$ sulphur content in fuel, and a total of $90 \times 10^{6}$ ton fuel use per year for all vessels in the right bank of the Antwerp harbour were assumed. The model was run to steady state to assess the difference in water composition in the docks with and without scrubbers. Carbonate balances were computed with the R package AquaEnv [37]. The model was integrated with the $\mathrm{R}$ package deSolve [38]. The model code and scripts to run the scenario analyses are available on GitHub [link to the model will be made available upon acceptance].

\section{Results and discussion}

\section{Scrubber washwater quality}

To get insight in the concentrations of contaminants present in scrubber washwater a database was compiled (Additional file 1: Table S1). Metal and PAH concentrations in water that is discharged were found to be elevated compared to surface water concentrations or Water Quality Standards (WQS) (Table 1, Additional file 2: Table S3). Differences between open- and closed-loop systems exist. The washwater in closed-loop scrubbers circulates within the system, contaminants accumulate over time, resulting in higher concentrations of metals (on average 40 times higher) and PAHs (on average 1.3 times higher) in the discharged water compared to open-loop mode (2-way ANOVA; metals: $F_{1,323}=26,7$; $p<0.001$, PAH: $F_{1,475}=7.27 ; p=0.007$ ) (Fig. 1 ). However, in closed-loop scrubbers the scrubbing capacity is kept high by dosing sodium hydroxide resulting in a low volume of water needed to trap $\mathrm{SO}_{x}$ efficiently. Closedloop systems discharge discontinuous and lower volumes of washwater (bleed-off) with a calculated average volume of $0.47 \mathrm{~m}^{3} \mathrm{MWh}^{-1}$ (STDEV $\left.=0.0 .25, N=7\right)$. In contrast, open-loop systems need a large volume of surface water to ensure removal of $\mathrm{SO}_{\mathrm{x}}$ from the exhaust with discharge volumes that are roughly 200 times
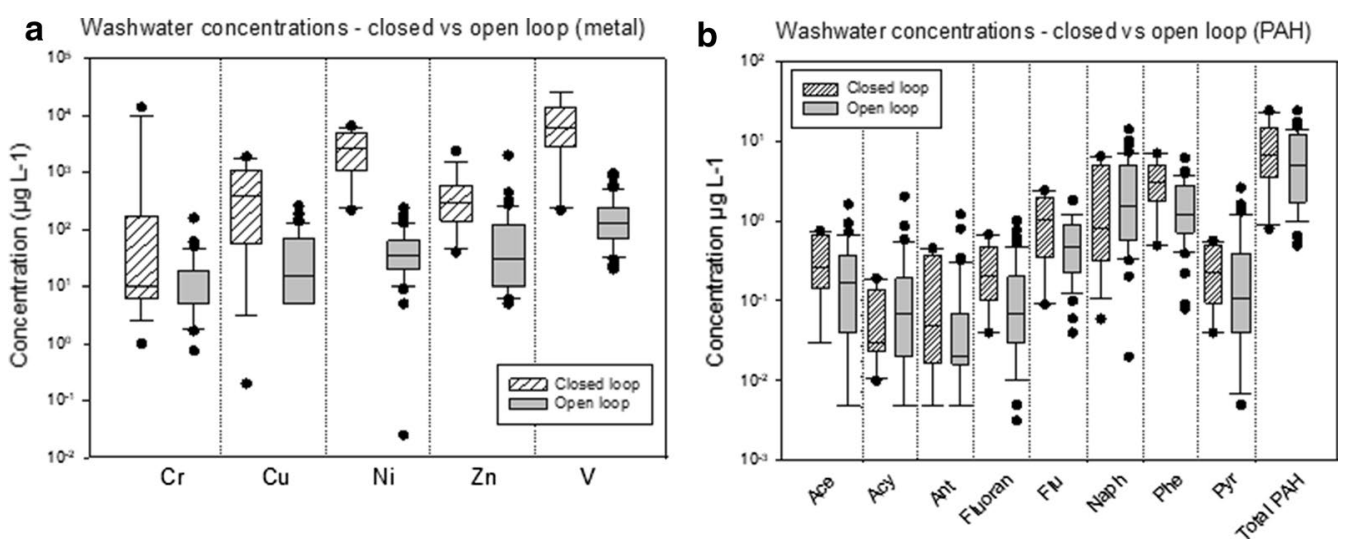

Fig. 1 Metal (a) and PAH (b) concentrations $\left(\mu \mathrm{g}^{-1}\right)$ in washwater from scrubbers operating in closed-loop (shaded boxes) and open-loop (grey boxes). Boxplots with 5th and 95th percentile (whiskers), 25th, median and 75th percentile and outliers (dots). Y-axis in logarithmic scale 
higher (calculated average $87 \mathrm{~m}^{3} \mathrm{MWh}^{-1}, \mathrm{STDEV}=50$, $N=44$ ). The circulation of water and smaller washwater volumes when operating in closed loop allows efficient treatment of the washwater using a hydrocyclone with removal of particles before discharge. Hereby, contaminants are scavenged in a sludge fraction that is stored and delivered to port reception facilities resulting in a lower total discharge of contaminants to the surrounding surface water (6 times for metals and 183 times for PAHs) for scrubbers operating in closed loop mode (differences are significant for metals: 2-way ANOVA; $F_{1,323}=6.56$; $p=0.011$ and PAHs: $F_{1,475}=30.4 ; p<0.001$ ) (Fig. 2). The differences between metals and PAHs in total discharge indicate that PAHs are trapped much more efficient in the sludge fraction than metals by hydrocyclone treatment in closed loop mode. Also for scrubbers operating in open loop, the use of washwater treatment systems is reported (Additional file 1: Table S1). However, treatment of the large washwater flow rates is less straightforward. A vessel sailing with $15 \mathrm{MW}$ engine power will discharge roughly $350 \mathrm{~L} \mathrm{~s}^{-1}$. The large variation in concentrations and the limited number of scrubbers that reported an open-loop system with treatment in the dataset did not allow to draw conclusions on differences in concentrations between open-loop with and without treatment. The acidity of the washwater in the closed-loop mode can be controlled by dosing the scrubbing media $\mathrm{NaOH}$ resulting in higher average $\mathrm{pH}$ values in the discharged water $(6.8, \mathrm{STDEV}=1.7, n=6)$ compared to the average $\mathrm{pH}$ values in open-loop mode $(4.8, \mathrm{STDEV}=1.4, n=21)$.

Also within closed- and open-loop systems the variation in concentrations for the different parameters is large (Fig. 1). This variation can be attributed to many different factors including fuel origin [39], fuel sulphur content [40], engine load [15], additives, or the presence of treatment facilities before the washwater is discharged. In general, the contaminants originating from the fuel, lubricant oil or combustion process, are transported to the smokestack, washed out by the scrubber water and end up in the washwater. Metal concentrations in fuels are known to vary substantially and are related to the crude oil origin and refinery process [39]. Since a substantial part of the metals in the fuel is expected to end up in the scrubber washwater $[16,18]$, the fuel origin will directly affect the washwater metal concentrations. Vessels with scrubbers usually operate on high-sulphur fuel oil (HSFO). These are residual fuels that are known to contain higher concentrations of metals compared to distillate fuel (DF), e.g. MGO [41]. The metals $\mathrm{V}$ and $\mathrm{Ni}$ and to a lesser extent $\mathrm{Cu}$ are typically tracers for residual fuel. For $\mathrm{Zn}$ the fuel and the lubricant oil have been reported to contribute equally to the emissions [41, 42]. Also in the present study $\mathrm{V}, \mathrm{Zn}, \mathrm{Ni}$ and $\mathrm{Cu}$ are the metals that were measured in the highest concentrations in the scrubber washwater. In open-loop scrubbers average washwater concentrations with standard deviation (STDEV) were $200 \mu \mathrm{g} \mathrm{L}^{-1}$ (STDEV $125 \mu \mathrm{g} \mathrm{L}^{-1}$ ) for $\mathrm{V}$, $111 \mu \mathrm{g} \mathrm{L}^{-1}$ (STDEV $30 \mu \mathrm{g} \mathrm{L}^{-1}$ ) for Zn, $52 \mu \mathrm{g} \mathrm{L}^{-1}$ (STDEV $\left.34 \mu \mathrm{g} \mathrm{L}^{-1}\right)$ for $\mathrm{Ni}$ and $43 \mu \mathrm{g} \mathrm{L} \mathrm{L}^{-1}$ (STDEV $15 \mu \mathrm{g} \mathrm{\textrm {L } ^ { - 1 }}$ ) for $\mathrm{Cu}$. Concentrations in bleed-off from closed loop scrubbers were $9256 \mu \mathrm{g} \mathrm{L}^{-1}$ (STDEV $6050 \mu \mathrm{g} \mathrm{L}^{-1}$ ) for $\mathrm{V}, 469 \mu \mathrm{g} \mathrm{L}^{-1}$ (STDEV $290 \mu \mathrm{g} \mathrm{L}^{-1}$ ) for $\mathrm{Zn}, 2810 \mu \mathrm{g} \mathrm{L}^{-1}$ (STDEV $2700 \mu \mathrm{g} \mathrm{L}^{-1}$ ) for $\mathrm{Ni}$ and $584 \mu \mathrm{g} \mathrm{L}^{-1}$ (STDEV $390 \mu \mathrm{g} \mathrm{L}^{-1}$ ) for $\mathrm{Cu}$. Besides, the concentration of $\mathrm{Cr}$ was found to be high in the washwater of several scrubbers operating in closed loop, while for most other washwater samples no elevated concentrations were measured. It is not clear where the high concentrations originate from, as $\mathrm{Cr}$ is generally not present in fuel [41]. It is possible that corrosion or abrasion of the scrubber installation, a Metal flux - closed vs open loop

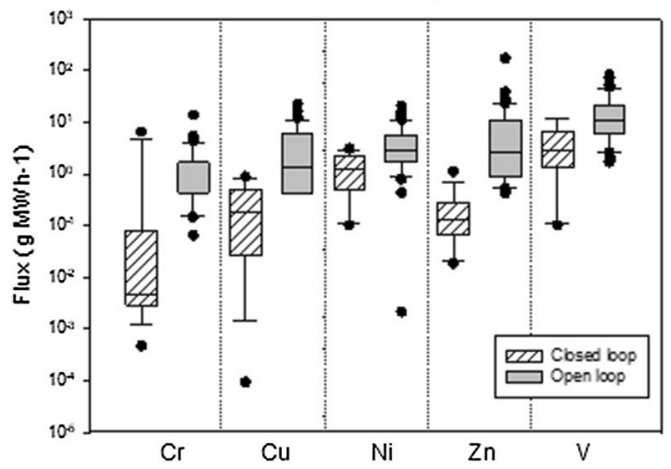

b PAH flux - closed vs open loop

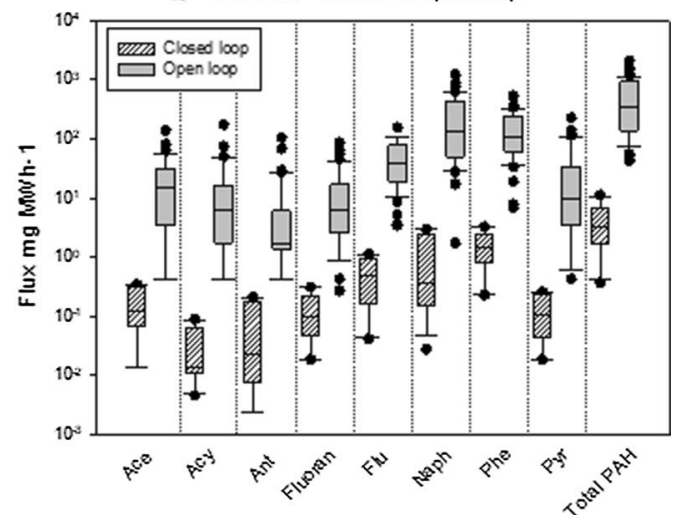

Fig. 2 Total discharge $\left(\mathrm{g} \mathrm{MWh}^{-1}\right.$ ) of metals (a) and PAHs (b) in washwater from scrubbers operating in closed loop (shaded boxes) and open loop (grey boxes). Boxplots with 5th and 95th percentile (whiskers), 25th, median and 75th percentile and outliers (dots). Y-axis in logarithmic scale 
stimulated by the acidic washwater, is a source of $\mathrm{Cr}$, as was previously suggested for $\mathrm{Cu}[24,27]$.

The higher emissions originating from combusting HSFO compared to DF, as reported for metals, is even more pronounced for PAHs, with atmospheric emissions reported to be 200 times higher when operating on HSFO [15]. In the case of HSFO, the PAHs in the exhaust generally originate directly from the fuel [15]. The PAH concentrations in the emissions of marine engines are found to be dominated by Phe, Naph, Fluoran and Flu [43], which corresponds to the PAHs that were measured in high concentration in the washwater of present study with average values and STDEV in open-loop washwater of $2889 \mathrm{ng} \mathrm{L}^{-1}$ (STDEV $2987 \mathrm{ng} \mathrm{L}^{-1}$ ) for Naph, $1685 \mathrm{ng} \mathrm{L}^{-1}$ (STDEV $1367 \mathrm{ng} \mathrm{L}^{-1}$ ) for Phe, $583 \mathrm{ng} \mathrm{L}^{-1}$ (STDEV $415 \mathrm{ng} \mathrm{L}^{-1}$ ) for Flu and $162 \mathrm{ng} \mathrm{L}^{-1}$ (STDEV $215 \mathrm{ng} \mathrm{L}^{-1}$ ) for Fluoran and closed loop bleed-off concentrations of $2175 \mathrm{ng} \mathrm{L}^{-1}$ (STDEV $2409 \mathrm{ng} \mathrm{L}^{-1}$ ) for Naph, $3360 \mathrm{ng} \mathrm{L}^{-1}$ (STDEV $2146 \mathrm{ng} \mathrm{L}^{-1}$ ) for Phe, $1148 \mathrm{ng}$ $\mathrm{L}^{-1}$ (STDEV $815 \mathrm{ng} \mathrm{L}^{-1}$ ) for Flu and $280 \mathrm{ng} \mathrm{L}^{-1}$ (STDEV $210 \mathrm{ng} \mathrm{L}^{-1}$ ) for Fluoran.

\section{Impact on water quality}

The concentrations of most PAHs and all metals in closed loop bleed-off largely exceeded their WQS (Table 1, Additional file 2: Table S3) and are expected to be acutely toxic for most aquatic organisms. Acute toxic effects of scrubber washwater on phyto- and zooplankton are reported, even at concentrations of metals and PAHs much lower than the concentrations reported in present work $[23,25]$. The synergistic effects caused by the mixture of metals and PAHs combined with low $\mathrm{pH}$ in scrubber washwater result in higher toxicity than estimated from the effect thresholds of the individual compounds [23, 44]. Acidification of the surface water can furthermore change the behaviour of metals in the receiving aquatic ecosystems. A decrease in $\mathrm{pH}$ can result in a higher bioavailability and in increase in remobilisation of metals from the sediment. However, the effects of washwater are strongly influenced by dilution with surrounding surface water. Buhaug et al. [28] modelled that washwater at $50 \mathrm{~m}$ behind the vessels will be diluted 2000 times for vessels sailing in open sea and 1750 times during port operation at lower speed. The extent of dilution will depend on vessel activity (at berth, manoeuvring, sailing) and physical characteristics of the receiving water body such as dimensions and flow rate, which complicates the prediction of scrubber washwater toxicity. When applying the dilution factor of 2000 on washwater metal and PAH concentrations almost no compounds will exceed their WQS, whereby no acute toxicity is expected.
The increase in metal and PAH concentrations in aquatic ecosystems that originate from scrubber washwater is expected to be higher in inland waterbodies such as estuaries, rivers or harbours compared to large open marine systems. The accumulation of metals and PAHs in the surface water of the Antwerp harbour docks and the Scheldt estuary was calculated for a 'scenario LOW' (10\% open-loop scrubbers and average washwater concentrations) and a 'scenario HIGH' (20\% open-loop scrubbers and 90th percentile washwater concentrations) (Fig. 3). In particular, the concentration of several PAHs (Flu, Naph and Phen) in the surface water of the Antwerp harbour docks was simulated to increase due to scrubber discharge. An increase in concentration of 39\% under the 'scenario LOW' and $189 \%$ under the 'scenario HIGH' was calculated for naphthalene. The mean concentration of vanadium in the docks would increase with $9 \%$ under scenario LOW and $46 \%$ under scenario HIGH. The time vessels spend in the Scheldt estuary is shorter than in the harbour docks, which resulted in lower total amount of fuel use, a lower volume of scrubber washwater discharged and a smaller effect on metal and PAH concentrations in the surface water compared to the docks. For the Scheldt estuary mean naphthalene concentrations were calculated to increase with $5.0 \%$ (scenario LOW) to $25 \%$ (scenario HIGH). For vessels with scrubbers in closed loop mode a large part of the metals and PAHs is removed from the washwater, trapped in the sludge fraction and delivered on shore, with a smaller increase in pollutant concentrations as a consequence (Table 1). The estimated increase in surface water metal and PAH concentrations are worst case calculations as the assumption was made that contaminants stay in suspension, i.e. during their stay in the docks with an average residence time of 19 days. However, metals and PAHs might be removed from the water by adsorption to suspended solids followed by sedimentation. Furthermore, PAHs can be degraded by biological and chemical processes, with half-life values of 3 days to more than 500 days, depending on environmental conditions and the PAH being degraded [45]. Mainly the low molecular weight PAHs measured in high concentrations in the washwater (Naph, Phen, Flu) are known to degrade faster. In order to estimate the risks related to scrubber water discharge it is important to further investigate contaminant behaviour in the receiving water bodies. Yet, also in comparison with known existing emissions the total amount of contaminants discharged by scrubbers is large. The calculated flux of metals and PAHs from scrubber discharge under scenario HIGH was lager then the sum of all known emissions to the harbour docks for Naph (57 kg year ${ }^{-1}$ 


\section{Harbour docks}

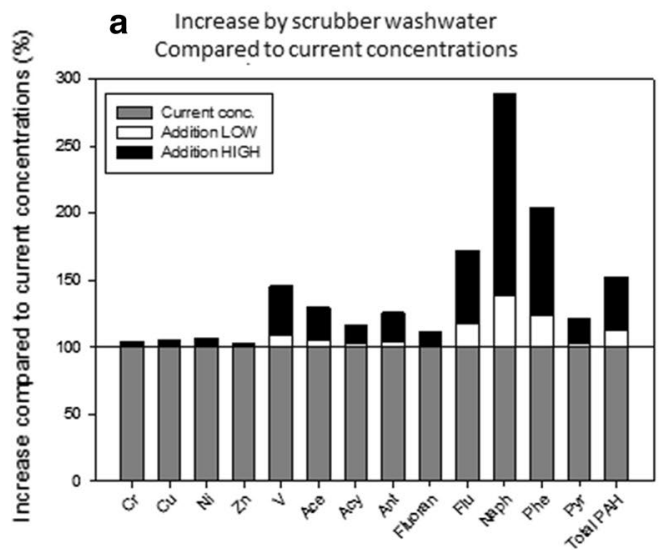

C Increase by scrubber washwater Compared to WOS

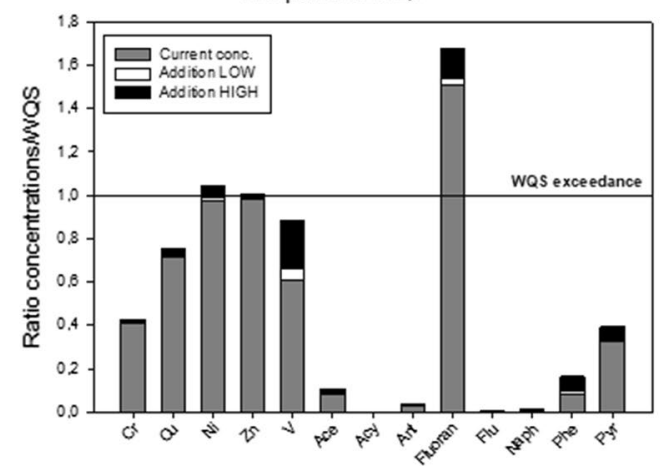

Scheldt estuary

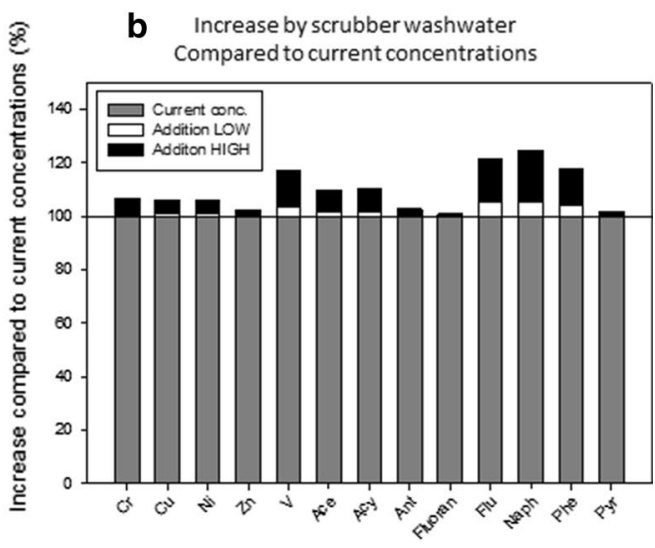

d Increase by scrubber washwater compared to WQS

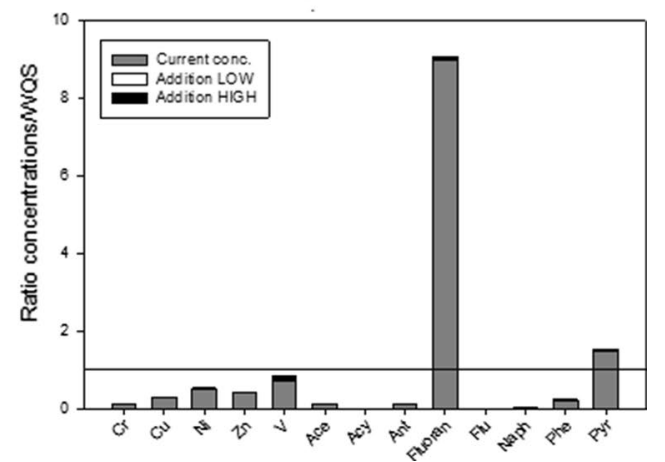

Fig. 3 Increase in metal and PAH surface water concentrations (\%) in the harbour docks (a) and the Scheldt estuary (b) caused by open loop scrubber discharge compared to current concentrations (grey, 100\%) calculated with the scenario LOW (white) and scenario HIGH (black). The ratio between water quality standards (WQS) and current (grey) metal and PAH surface water concentrations in the docks (c) and the Scheldt estuary. The calculated concentration increase caused by open-loop scrubber discharge calculated by the scenario LOW (white) and scenario HIGH (black)

for scrubbers compared to $19 \mathrm{~kg}$ year $^{-1}$ for all other sources), for Phen (30 kg year ${ }^{-1}$ for scrubbers compared to $11 \mathrm{~kg}_{\text {year }}{ }^{-1}$ for all other sources), Flu (10 kg year ${ }^{-1}$ for scrubbers compared to $6 \mathrm{~kg}_{\text {year }}{ }^{-1}$ for all other sources), and $\mathrm{Ni}$ ( $994 \mathrm{~kg} \mathrm{year}^{-1}$ for scrubbers compared to $60 \mathrm{~kg} \mathrm{year}^{-1}$ for all other sources) [46]. Some of the pollutants that are present in scrubber washwater are already exceeding (Flu, Pyr) or close to exceedance $(\mathrm{Ni}$, $\mathrm{Zn}$ ) of their respective WQS in the surface water of the harbour docks or the Scheldt estuary (Fig. 3). However, the compounds for which a large increase in concentrations was calculated (Naph $>$ Phe $>$ Flu $>$ Ace $>$ V) are not the compounds that are expected to pose the highest risk, based on the exceedances of the WQS. Nevertheless, several pollutants that were measured in elevated concentrations and discharged with the scrubber washwater are identified as 'priority substances' (Fluoran, Naph, Ni) or 'priority hazardous substances' (Ant,
B(a)P, Cd) by the European Water Framework Directive (WFD) and as such are of major concern for European Waters. WQS exceedances of these compounds indicate that these aquatic systems are under pressure of high contaminant concentrations and progressive reduction of pollution from priority substances and the cessation or phasing-out of discharges, emissions and losses of priority hazardous substances is required [47]. Many European coasts and estuaries are part of Natura 2000, the largest coordinated network of protected areas in the world to safeguard valuable and threatened species and habitats. Mainly in these areas with large ecological values the discharge of scrubber washwater should be restricted. In addition, the use of scrubbers deflect attention from development of cleaner fuels [48]. However, also the emissions from vessels operating on low sulphur fuel are variable and subject to changes. With the sulphur regulations, new types of low-sulphur heavy fuel oils (hybrid fuels, intermediate 
fuels or ECA fuels) have entered the market. How these fuels influence emission of metals and PAHs is not clear yet. It will, likely be necessary to limit the use of all low-quality fuels, with high and low sulphur content and instead encourage the use of distillate fuels, mainly in coasts, estuaries and inland water bodies with large ecological value [1].

\section{Acidification}

Marine transport-related emissions of $\mathrm{NO}_{\mathrm{x}}$ and $\mathrm{SO}_{\mathrm{x}}$ cause acidification of terrestrial and marine ecosystems [49]. The contribution of anthropogenic N and S depositions to ocean acidification account only for a few percent of the acidifying impact of the global anthropogenic emissions (mainly caused by $\mathrm{CO}_{2}$ ) [50]. However, in certain restricted areas such as coastal waters with important shipping lanes or large harbours, the acidifying effect caused by $\mathrm{NO}_{\mathrm{x}}$ and $\mathrm{SO}_{\mathrm{x}}$ can exceed the effect of overall anthropogenic $\mathrm{CO}_{2}$ emissions [49]. In open-loop scrubber systems the natural buffering capacity (alkalinity) of the sea or river water is used to neutralise the acid ions. Mean alkalinity in coastal waters varies between 2100 and $2400 \mu \mathrm{mol} \mathrm{L}^{-1}$ [51] and is high enough to guarantee high $\mathrm{SO}_{\mathrm{x}}$ removal efficiencies. Due to a calcium-rich bedrock, the mean alkalinity in the surface water of the Scheldt estuary $\left(4400 \mu \mathrm{mol} \mathrm{L}^{-1}\right)$ and the docks $\left(3400 \mu \mathrm{mol} \mathrm{L}^{-1}\right)$ is high. In closed-loop systems, the acidity of the washwater is buffered by dosing $\mathrm{NaOH}$ to the circulating washwater in order to have a bleed-off that is neutral ( $\mathrm{pH}$ around 6-8). Since vessels with scrubbers operate on high-sulphur fuel (up to $3.5 \%$ ), the acidifying sulphur compounds are discharged directly into the surface water and their acidifying capacity is much larger then vessels operating on low sulphur fuel $(0.1 \%$ in SECAs). Model simulations with scenario HIGH (20\% open loop scrubbers) show a decrease in $\mathrm{pH}$ of 0.015 units caused by washwater discharge (Fig. 4). The alkalinity will comparably decrease slightly with $6 \mu \mathrm{mol} \mathrm{L}^{-1}$ or $0.16 \%$ and total sulphate concentrations will increase with $3 \mu \mathrm{mol} \mathrm{L} \mathrm{L}^{-1}$ or $0.08 \%$. For the Baltic Sea, the water $\mathrm{pH}$ has previously been calculated to decrease by open-loop scrubber use with roughly 0.0015 units (50\% scrubbers scenario) to 0.003 units (100\% scrubbers scenario) [49].

Since preindustrial times global ocean $\mathrm{pH}$ decreased with approximately 0.1 units with related negative consequences for marine ecosystems [52]. Among many other sources, $\mathrm{SO}_{\mathrm{x}}$ emissions of marine transport contribute to this acidification. The IMO established sulphur regulations to mitigate the impact of high sulphur emissions of the maritime sector. However, the use of open-loop scrubbers as an abatement technology will not reduce their contribution to the acidification.

\section{Conclusions}

The number of vessels with a scrubber is increasing rapidly. Generally, the total acidifying potential and emissions of hazardous substances of vessels with scrubbers operating on HSFO are higher than from vessels operating on low sulphur compliant fuels. A substantial part of these emissions are directly discharged with the washwater into receiving aquatic ecosystems. This washwater is found to be acute toxic for aquatic organisms and a substantial long-term increase in the concentrations of Naph, Phe, Flu, Ace and $\mathrm{V}$ following scrubber washwater discharge was calculated for an estuary and harbour docks. The compounds for which a large increase in concentrations was calculated (Naph $>$ Phe $>$ Flu $>$ Ace $>$ V) are not the compounds that are expected to pose the highest risk, based on the exceedances of the WQS. Nevertheless, several pollutants that are discharged with the scrubber washwater are identified as 'priority substances' or

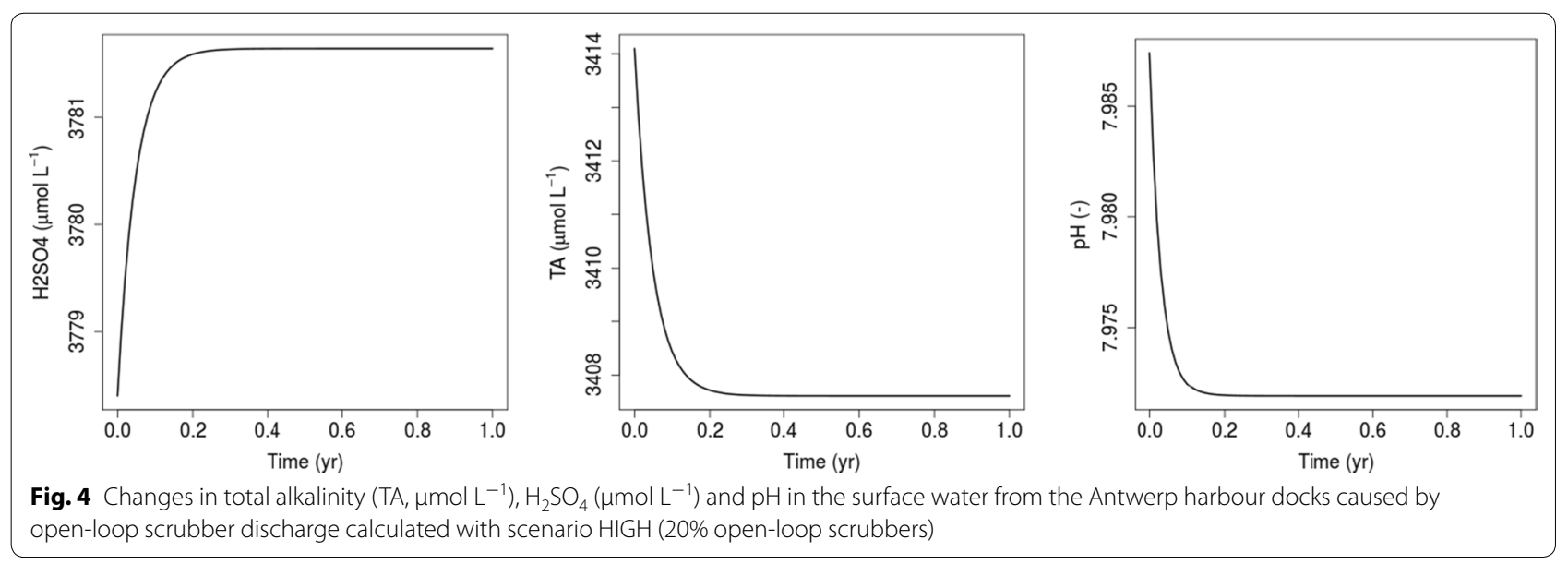


'priority hazardous substances' by the European Water Framework Directive and as such are of major concern for European Waters. WQS exceedances of these compounds indicate that many European aquatic systems are already under pressure. As such, mainly in coast and estuaries with large ecological values the discharge of scrubber washwater should be restricted.

\section{Supplementary information}

Supplementary information accompanies this paper at https://doi. org/10.1186/s12302-020-00380-z.

\section{Additional file 1: Table S1. An Excel file that contains the compiled} database on scrubber use and washwater quality. A total of 127 samples, based on own sampling, received datasets and literature.

Additional file 2: Table S2. All measured parameters with number of values below the limit of quantification. Table S3. Summarising numbers on scrubber washwater concentrations, fluxes and impact on water quality for scenario low (10\% scrubbers). The numbers of scenario high (20\% scrubbers) are included in the manuscript (Table 1). Figure S1. All scrubber washwater metal concentrations. Figure S2. All scrubber washwater PAH concentrations.

\section{Abbreviations}

IMO: International Maritime Organization; EGCS: Exhaust gas cleaning systems; PM: Particulate matter; MARPOL: International Convention for the Prevention of Pollution from Ships; S: Sulphur; SOx: Sulphur (x)oxide; SECA: Emission Control Area; LNG: Liquefied natural gas; $\mathrm{NaOH}$ : Sodium hydroxide; HFO: Heavy fuel oil; PAH: Polycyclic aromatic hydrocarbons; MGO: Marine gas oil; ECSA: European Community Shipowners' Association; HDPE: High-density polyethylene; ICP-OES: Inductively coupled plasma optical emission spectrometry; GC/MS: Gas chromatography/mass spectrometry; As: Arsenic; Cd: Cadmium; Cr: Chromium; Cu: Copper; Hg: Mercury; Pb: Lead; Ni: Nickel; Zn: Zinc; V: Vanadium; Ace: Acenaphthene; Acy: Acenaphthylene; Ant: Anthracene; B(a)A: Benzo(a)anthracene; B(a)P: Benzo(a)pyrene; B(b)F: Benzo(b)fluoranthene; B(ghi)P: Benzo(g,h,i)perylene; B(k)F: Benzo(k)fluoranthene; Chr: Chrysene; D(ah) A: Dibenzo(a,h)anthracene; Fluoran: Fluoranthene; Flu: Fluorene; I'123cd)P: Indeno(1,2,3c-d)pyrene; Naph: Naphthalene; Phe: Phenanthrene; Pyr: Pyrene; EGCSA: Exhaust gas cleaning system association; BLOQ: Below limit of quantification; TA: Total alkalinity; WQS: Water Quality Standards; HSFO: High-sulphur fuel oil; DF: Distillate fuel; STDEV: Standard deviation; WFD: Water Framework Directive.

\section{Acknowledgements}

We acknowledge the Antwerp Port Authority for cooperation, providing data and financial support. We are very grateful to the participating shipping companies for the fruitful cooperation and sharing of their data, to the EGCSA and Euroshore to make the data of their washwater sampling campaign available, to the Flemish Environmental Agency for their advice and data on the water quality and to the Royal Belgian Institute of Natural Sciences for their advice.

\section{Authors' contributions}

JT collected samples, performed chemical analysis, interpreted the data and drafted the manuscript. TJSC contributed to the calculations and revised the manuscript. KVI provided additional datasets and organized sampling campaigns. FJRM modelled the acidification and revised the manuscript. RB contributed to the study design and revised the manuscript. All authors read and approved the final manuscript.

\section{Funding}

This research was funded by the Antwerp Port Authority.

\section{Availability of data and materials}

All data generated or analysed during this study are included in this published article and its additional information files.
Ethics approval and consent to participate Not applicable.

\section{Consent for publication}

Not applicable.

\section{Competing interests}

The authors declare that they have no competing interests.

\section{Author details}

${ }^{1}$ Department of Biology, Systemic Physiological and Ecotoxicological Research, University of Antwerp, Groenenborgerlaan 171, 2020 Antwerp, Belgium. ${ }^{2}$ Department of Biology, Ecosystem Management Research Group, University of Antwerp, Universiteitsplein 1C, 2610 Wilrijk, Belgium. ${ }^{3}$ Department of Estuarine and Delta Systems, NIOZ Royal Netherlands Institute for Sea Research and Utrecht University, P.O. Box 140, 4400 AC Yerseke, The Netherlands. ${ }^{4}$ Antwerp Port Authority, Zaha Hadidplein 1, 2030 Antwerp, Belgium. ${ }^{5}$ Department of Biotechnology - Environmental Biotechnology, TU Delft, Van der Maasweg 9, 2629 HZ Delft, The Netherlands.

Received: 17 April 2020 Accepted: 14 July 2020

Published online: 23 July 2020

\section{References}

1. Andersson K, Brynolf S, Lindgren JF, Wilewska-Bien M (2016) Shipping and the environment: improving environmental performance in marine transport. Springer, Berlin, p 425

2. Sofiev M, Winebrake JJ, Johansson L, Carr EW, Prank M, Soares J, Vira J, Kouznetsov R, Jalkanen J-P, Corbett JJ (2018) Cleaner fuels for ships provide public health benefits with climate tradeoffs. Nat Commun 9(1):406

3. Claremar B, Haglund K, Rutgersson A (2017) Ship emissions and the use of current air cleaning technology: contributions to air pollution and acidification in the Baltic Sea. Earth Syst Dyn 8(4):901-919

4. Hassellöv I-M, Turner DR, Lauer A, Corbett JJ (2013) Shipping contributes to ocean acidification. Geophys Res Lett 40(11):2731-2736

5. Capaldo K, Corbett JJ, Kasibhatla P, Fischbeck P, Pandis SN (1999) Effects of ship emissions on sulphur cycling and radiative climate forcing over the ocean. Nature 400:743

6. Viana M, Hammingh P, Colette A, Querol X, Degraeuwe B, Vlieger I, van Aardenne J (2014) Impact of maritime transport emissions on coastal air quality in Europe. Atmos Environ 90:96-105

7. Corbett JJ, Winebrake JJ, Green EH, Kasibhatla P, Eyring V, Lauer A (2007) Mortality from ship emissions: a global assessment. Environ Sci Technol 41(24):8512-8518

8. EC (2012) The sulphur content of marine fuels 2012/33/EU

9. Andreasen A, Mayer S (2007) Use of seawater scrubbing for $\mathrm{SO} 2$ removal from marine engine exhaust gas. Energy Fuels 21(6):3274-3279

10. Lindstad HE, Rehn CF, Eskeland GS (2017) Sulphur abatement globally in maritime shipping. Transp Res Part D Transp Environ 57:303-313

11. Nikopoulou Z (2017) Incremental costs for reduction of air pollution from ships: a case study on North European emission control area. Marit Policy Manage 44(8):1056-1077

12. Jiang L, Kronbak J, Christensen LP (2014) The costs and benefits of sulphur reduction measures: sulphur scrubbers versus marine gas oil. Transp Res Part D Transp Environ 28:19-27

13. Panasiuk I, Turkina $L$ (2015) The evaluation of investments efficiency of SOx scrubber installation. Transp Res Part D Transp Environ 40:87-96

14. Carr EW, Corbett JJ (2015) Ship compliance in emission control areas: technology costs and policy instruments. Environ Sci Technol 49(16):9584-9591

15. Sippula O, Stengel B, Sklorz M, Streibel T, Rabe R, Orasche J, Lintelmann J, Michalke B, Abbaszade G, Radischat C, Gröger T, Schnelle-Kreis J, Harndorf H, Zimmermann R (2014) Particle emissions from a marine engine: chemical composition and aromatic emission profiles under various operating conditions. Environ Sci Technol 48(19):11721-11729

16. Fridell E, Salo K (2014) Measurements of abatement of particles and exhaust gases in a marine gas scrubber. Proc Inst Mech Eng Part M J Eng Marit Environ 230(1):154-162 
17. Di Natale F, Carotenuto C (2015) Particulate matter in marine diesel engines exhausts: emissions and control strategies. Transp Res Part D Transp Environ 40:166-191

18. Endres S, Maes F, Hopkins F, Houghton K, Mårtensson EM, Oeffner J, Quack B, Singh P, Turner D (2018) A new perspective at the ship-air-seainterface: the environmental impacts of exhaust gas scrubber discharge. Front Mar Sci. 5:139

19. Bengtsson S, Andersson K, Fridell E (2011) Life cycle assessment of marine fuels. A comparative study of four fossil fuels for marine propulsion; Technical report no 11:125; Chalmers University of Technology: Gothenburg, Sweden

20. Andersson K, Brynolf S (2016) Fuels in the Baltic Sea after SECA, Report Trafikanalys

21. Winnes H, Fridell E, Moldanova J (2020) Effects of marine exhaust gas scrubbers on gas and particle emissions. J Mar Sci Eng 8(4):299

22. Lehtoranta K, Aakko-Saksa P, Murtonen T, Vesala H, Ntziachristos L, Rönkkö T, Karjalainen P, Kuittinen N, Timonen H (2019) Particulate mass and nonvolatile particle number emissions from marine engines using low-sulfur fuels, natural gas, or scrubbers. Environ Sci Technol 53(6):3315-3322

23. Koski M, Stedmon C, Trapp S (2017) Ecological effects of scrubber water discharge on coastal plankton: potential synergistic effects of contaminants reduce survival and feeding of the copepod Acartia tonsa. Mar Environ Res 129:374-385

24. Kjølholt J, Aakre S, Jürgensen C, Lauridsen J (2012) Assessment of possible impacts of scrubber water discharges on the marine environment. Report of The Danish Environmental Protection Agency

25. Ytreberg E, Hassellöv I-M, Nylund AT, Hedblom M, Al-Handal AY, Wulff A (2019) Effects of scrubber washwater discharge on microplankton in the Baltic Sea. Mar Pollut Bull 145:316-324

26. Turner DR, Hassellov IM, Ytreberg E, Rutgersson A (2017) Shipping and the environment: smokestack emissions, scrubbers and unregulated oceanic consequences. Elementa Sci Anthropocene. https://doi.org/10.1525/ elementa.167

27. Hufnagl M, Liebezeit G, Behrends B (2005) Effects of sea water scrubbing. Final report

28. Buhaug O, Fløgstad H, Bakke T (2006) MARULS WP3: washwater criteria for seawater exhaust gas-SOx scrubbers. MARINTEC REPORT

29. USEPA (2011) Exhaust gas scrubber washwater effluent. Regulatory document. US Environmental Protection Agency

30. Lange B, Markus T, Helfst $L$ (2015) Impacts of scrubbers on the environmental situation in ports and coastal waters. Dessau-Roßlau

31. den Boer E,'t Hoen M (2015) Scrubbers - an economic and ecological assessment. CE Delft, Delft

32. Belgian Government, Wet oppervlaktewateren (1971) 26 maart 1971 - Wet op de bescherming van de oppervlaktewateren tegen verontreiniging

33. ECSA, European Community Shipowners' Association Open letter to EU Member States and the European Commission (2014) 18/06/2014. Implementation of the EU Sulphur Directive must be harmonised and realistic

34. International-Maritime-Organisation, Marine Environmental Protection Committee, 73rd session (2018) Annex: Report on analyses of water samples from exhaust gas cleaning systems. MEPC 73/INF.5

35. Hansen JP (2012) Exhaust gas scrubber installed onboard MV Ficaria seaways. Public test report from The Danisch Environmental Protection Agency and Alfa Laval

36. Gotze HJ, Neddenien S, Ulrich E (1997) Onboard Measurements of diesel engine exhaust gas components. Trans Built Environ. https://doi. org/10.2495/MTECH970381
37. Hofmann AF, Soetaert K, Middelburg JJ, Meysman FJR (2010) AquaEnv: an aquatic acid-base modelling environment in R. Aquat Geochem 16(4):507-546

38. Soetaert K, Petzoldt T, Setzer RW (2010) Solving differential equations in R: package deSolve. J Stat Softw 33(9):1-25

39. Agrawal H, Eden R, Zhang X, Fine PM, Katzenstein A, Miller JW, Ospital J, Teffera S, Cocker DR (2009) Primary particulate matter from oceangoing engines in the Southern California Air Basin. Environ Sci Technol 43(14):5398-5402

40. Winnes H, Moldanova J, Anderson M, Fridell E (2016) On-board measurements of particle emissions from marine engines using fuels with different sulphur content. Proc Inst Mech Eng Part M J Eng Marit Environ 230(1):45-54

41. Celo V, Dabek-Zlotorzynska E, McCurdy M (2015) Chemical characterization of exhaust emissions from selected canadian marine vessels: the case of trace metals and lanthanoids. Environ Sci Technol 49(8):5220-5226

42. Moldanová J, Fridell E, Winnes H, Holmin-Fridell S, Boman J, Jedynska A, Tishkova V, Demirdjian B, Joulie S, Bladt H, Ivleva NP, Niessner R (2013) Physical and chemical characterisation of PM emissions from two ships operating in European Emission Control Areas. Atmos Meas Tech 6(12):3577-3596

43. Contini D, Gambaro A, Belosi F, De Pieri S, Cairns WRL, Donateo A, Zanotto E, Citron M (2011) The direct influence of ship traffic on atmospheric PM2.5, PM10 and PAH in Venice. J Environ Manag 92(9):2119-2129

44. Gauthier PT, Norwood WP, Prepas EE, Pyle GG (2014) Metal-PAH mixtures in the aquatic environment: a review of co-toxic mechanisms leading to more-than-additive outcomes. Aquat Toxicol 154:253-269

45. Ghosal D, Ghosh S, Dutta TK, Ahn Y (2016) Current state of knowledge in microbial degradation of polycyclic aromatic hydrocarbons (PAHs): a review. Front Microbiol 7:1369

46. van Duijnhoven N, van den Roovaart J, Desmet N, van Esch L, Seuntjes P (2013) Specific emissions to the surface water in the Antwerp harbour docks (Report in Dutch: Specifieke emissies naar het oppervlaktewater in het Antwerpse Havengebied, Deltares en Vito)

47. EC (2013) Water framework directive on priority substances 2013/39/EU

48. Lindstad HE, Eskeland GS (2016) Environmental regulations in shipping: policies leaning towards global'ation of scrubbers deserve scrutiny. Transp Res Part D Transp Environ 47:67-76

49. Turner DR, Edman M, Gallego-Urrea JA, Claremar B, Hassellöv I-M, Omstedt A, Rutgersson AJA (2018) The potential future contribution of shipping to acidification of the Baltic Sea. Ambio 47(3):368-378

50. Doney SC, Mahowald N, Lima I, Feely RA, Mackenzie FT, Lamarque J-F, Rasch PJ (2007) Impact of anthropogenic atmospheric nitrogen and sulfur deposition on ocean acidification and the inorganic carbon system. Proc Natl Acad Sci 104(37):14580-14585

51. Lee K, Tong LT, Millero FJ, Sabine CL, Dickson AG, Goyet C, Park GH, Wanninkhof R, Feely RA, Key RM (2006) Global relationships of total alkalinity with salinity and temperature in surface waters of the world's oceans. Geophys Res Lett. https://doi.org/10.1029/2006GL027207

52. Doney SC, Fabry VJ, Feely RA, Kleypas JA (2009) Ocean acidification: the other CO2 problem. Ann Rev Mar Sci 1:169-192

\section{Publisher's Note}

Springer Nature remains neutral with regard to jurisdictional claims in published maps and institutional affiliations. 